\title{
Preface. Creatures of Silence
}

The early twenty-first century has been marked by a series of crimes and tragedies revealing, to the apparent surprise of many Americans, the longevity and pervasiveness of racism in the United States. Despite the fiftieth anniversary of important landmarks of civil rights legislation and the election of the nation's first African American president, a "postracial" future has not arrived. The bluntly discriminatory administration of justice reveals that the day-to-day lived experience of many nonwhite Americans differs significantly from that of whites. These sadly repeated discoveries of crude discrimination inspire equally regular calls for a "national conversation on race."

Considering how much the subject of race is openly debated at the beginning of the twenty-first century, it seems surprising that the need for further discussion is consistently invoked. But in the United States, race, for all its notoriety, is usually talked about in intimate contexts among people expected to hold roughly the same opinion. It is too loaded a topic to explore with strangers. Although it is a subject that affects the entire nation, there is nothing "national" about the conversation about race. In a society still much more segregated than we like to admit, it is difficult to talk freely, and frankly, about race.

In the thirty-five years before the Civil War, it was comparatively easy, for white people at least, to talk about race, to broadcast what today seems blindingly hateful and woefully ignorant and to present it as scientific fact. ${ }^{1}$ "At least 3/5ths of the northerners now believe the blacks are an inferior race," estimated abolitionist Theodore Dwight Weld in $1836 .{ }^{2}$ Not all white people declared blacks were less than human, but most believed they were decidedly less than whites. Even if people of African descent were free, declared Supreme Court Justice Roger Taney in the Dred Scott decision, they could never be citizens, and "the special rights and immunities guarantied to citizens do not apply to them." 
But slavery was harder to discuss. As Ralph Waldo Emerson said, "[Slavery] does not love the newspaper, the mailbag, a college, a book, or a preacher who has the absurd whim of saying what he thinks." 4 To talk about slavery was to explore-or deny-its obvious shortcomings, its inhumanity, its contradictions. To celebrate it required explaining away the nation's proclaimed belief in equality and its public promise of rights for all. To condemn it was to insult people who might be related by ties of blood or friendship or business, to threaten the very economy and political stability of the nation. The effects of the suppression of open discussion concerned thoughtful Americans: "Sooner or later [slavery] must be discussed," wrote abolitionist Amos Phelps in 1834. "Silence will never mend the matter. The very evil, that threatens us with such ruin, is in itself the creature of silence." ${ }^{5}$

There were certainly partisans who chose sides in the debate, and more and more people identified themselves as opponents or supporters of slavery as the Civil War approached. But there were many, many others who hesitated to express what they thought for fear of unpleasant or even dire consequences. And the partisans increasingly found themselves corneredpublicly championing one side in the debate over slavery, but privately doubtful and unable to ignore weaknesses in their position.

How these people talked about what they hesitated to say-how they had a national conversation about slavery by talking about nations other than the United States-is the subject of this book. 